\title{
Effect of Squid Powder (Loligo Sp.) On Antibody Titer and Bacteria Density in Blood of Tilapia (Oreochromis niloticus) infected by Aeromonas hydrophila.
}

\author{
Mohamad Fadjar $^{1 *}$, Ellana Sanoesi ${ }^{1}$, Yoga Aris Mintya ${ }^{1}$, Lukmanul Hakim ${ }^{1}$ \\ ${ }^{1}$ Aquaculture Department, Fac. of Fisheries and Marine Science, University of Brawijaya, Malang, \\ Indonesia. \\ Corresponding Email : f4dj4r_02@ub.ac.id
}

Received : 12 April 2020; Accepted: 28 Mei 2020

\begin{abstract}
Mohamad Fadjar, Ellana Sanoesi, Yoga Aris Mintya, Lukmanul Hakim. 2020. Effect of Squid Powder (Loligo Sp.) On Antibody Titer and Bacteria Density in Blood of Tilapia (Oreochromis niloticus) infected by Aeromonas hydrophila. Aquacultura Indonesiana, 21 (1): 24 - 31. Aeromonas hydrophila is bacterium that often infect freshwater fish and causes Motile Aeromonas Septicemia (MAS) disease. One alternative antibacterial that can be used is squid ink (Loligo sp.) which contains antibacterial substances. The purpose of this study was to determine the effect of squid ink (Loligo sp.) on antibody titers and bacterial density in tilapia infected with A. hydrophila.

This study used a Completely Randomized Design (CRD) with the treatment of squid ink powder in feed at a dose of $52.5 \mathrm{ppm}(\mathrm{A}), 62.5 \mathrm{ppm}(\mathrm{B})$ and $72.5 \mathrm{ppm}(\mathrm{C})$, positive control (K+) using oxytetracycline ( 20 $\mathrm{ppm}$ ) on feed and negative control (K-) without giving treatment to feed. The main parameters observed were bacterial density in the blood of tilapia (O. niloticus) and antibody titer. In addition to the main parameters, supporting parameters observed in this study included survival rate (SR), and measurements of water quality (temperature, $\mathrm{DO}$ and $\mathrm{pH}$ ).

The best dose in giving squid ink (Loligo sp.) powder in feed was $62.5 \mathrm{ppm}$ (treatment B) because it surpressing bacterial density in the blood of tilapia (O. niloticus) until $1.66 \times 10^{5} \mathrm{cfu} / \mathrm{mL}$, decreasing antibody titer from $26.67 \pm 09.24 \%$ to $13.00 \pm 04.62 \%$ and highest survival rate of $90.47 \%$.
\end{abstract}

.Keywords : MAS, O. niloticus, Squid ink, Antibody, Blood.

\section{Introduction}

Tilapia (Oreochromis niloticus) is a freshwater aquaculture commodity that is widely known in the community and has become a mainstay commodity in several cities to support national food security and increase exports of fisheries commodities. The value of tilapia production continues to increase every year with an average increase in production value per year of $45.81 \%$. However, the high production value of tilapia (O. niloticus) still has problems including the form of disease problems that often attack aquaculture which often results in mass death (KKP, 2014).

Aeromonas hydrophila is a gramnegative bacterium that causes hemorrhagic septicemia or motile aeromonads septicemia (MAS) with high mortality in freshwater fish species and different growth stages (Liu, et al.,
2015). Symptoms of MAS include tissue swelling, red sores, necrosis, ulceration, and hemorrhagic septicemia. The fish species most commonly affected by MAS include tilapia, catfish, carp. Although A. hydrophila is usually considered a secondary pathogen associated with disease outbreaks, it can also appear as a major pathogen causing epidemics in fish farming with high mortality rates and serious economic losses to aquaculture. (False, et al., 2015). To control MAS, infected fish can be treated with antibiotics through feed or soaking. However, this practice is expensive and usually ineffective because sick fish tend not to eat. In addition, MAS caused by $A$. hydrophila is an acute infection that causes mortality within 24 hours (Sugiani, et al., 2018)

Proper production management must be carried out in this matter starting from health management, such as increasing the 
immune system, providing antibacterial antibiotics and maintaining survival (Miranti, 2016). Followed by Sari, et al. (2015), that treatment with antibiotics has been largely abandoned because it causes problems in the form of bacteria that become resistant to antibiotics to residues that endanger humans who consume them. Other alternatives are needed that can act as antibacterial. One of the anti-bacterial alternatives that can be used squid ink, this is by accordance with the statement of Fadjar, et al. (2016), one of the natural ingredients that has antibacterial ability is squid ink (Loligo sp.) which can damage the communication of bacteria with its host. This research will examine the effect of squid ink (Loligo sp.) powder on antibody titers and bacterial density in the blood of tilapia infected with $A$. hydrophila.

\section{Materials and Methods}

\section{Materials}

The materials used in this study were 7 - $13 \mathrm{~cm}$ tilapia (O. niloticus) with average body weight of $\pm 13.22 \mathrm{~g}$ from UPBAT Punten, Batu, Jawa Timur (5G4G+93 Batu, Kota Batu, Jawa Timur). Density per aquarium was 15 fish. A. hydrophila was got from Balai Besar Perikanan Budidaya Air Payau (BBPBAP) Jepara, Jawa Tengah (CJ7V+7Q Jepara, Kabupaten Jepara, Jawa Tengah). Squid ink powder was made using spray drying. Fish was fed with commersial feed.

\section{Methods}

The research method used in the study was the experimental method. using a Completely Randomized Design (CRD). The treatments used were 5 treatments including control with 3 replications, namely the administration of squid ink (Loligo sp.) to tilapia (O. niloticus) which had been infected with A. hydrophila with a treatment dose of $52.5 \mathrm{ppm}$ (A ), $62.5 \mathrm{ppm}$ (B) and $72.5 \mathrm{ppm}$ (C). The treatment of $\mathrm{K}+$ (positive control) with $20 \mathrm{ppm}$ artificial antibiotics oxytetracycline and infected by A. hydrophila and $\mathrm{K}$ - (negative control) infection of $\mathrm{A}$. hydrophila but no additional squid ink powder or oxytetracycline. The main parameters observed were bacterial density in blood and tilapia antibody titer. In addition to the main parameters, supporting parameters observed in this study included survival rate (SR), and water quality (temperature, $\mathrm{DO}$ and $\mathrm{pH}$ )..

\section{Infection of $A$. hydropila}

Tilapia (O. niloticus) was put into the aquarium and adapted for 24 hours. The infection was carried out using a 60 minute immersion method based on Wahjuningrum et al. (2013), in aquariums that contained $A$. hydrophila with a density of $10^{7} \mathrm{cfu} / \mathrm{mL}$

\section{Fish feed}

Feeding that has been mixed with squid ink powder was carried out three times a day at $08.00 \mathrm{am}, 12.00 \mathrm{pm}, 16.00 \mathrm{pm}$, as much as $5 \%$ of the total biomass / day. The feed was given to fish for seven days and observed clinical symptoms after treatment with squid ink powder.

\section{Antibody Titer Test}

Blood sampling for antibody titer test was carried out one day after A. hydrophila infection, four and seven days after squid ink (Loligo sp.) administration. How to count antibody titers: 12 wells on a microtiter plate were observed. The leftmost well is a positive control, while the rightmost well is a negative control. The formation of antibody titers is marked by the agglutination between antigens and antibodies that appear from the emergence of murky layers such as clouds in microplate wells, whereas in wells that do not form antibodies are marked with a dot at the bottom of the well which indicates the presence of a precipitating antigen (no agglutination occurs).

The antibody titer calculation starts from the first dilution (1) to 10 (from the 2 nd to 11th well). The antibody titer value is the opposite of the dilution series. For example, if agglutination occurs until the 6th well (dilution 32), the antibody titer formed is 32 . The purpose of dilution is to determine the ability of specific antibodies to bind to the dissolved antigen, so that the ability to know is the antibody titer value.

\section{Bacteria count in tilapia blood}

Calculation of bacterial density is calculated based on Mubarak, et al., (2016) 
through the blood of tilapia (O. niloticus). and planting bacteria. Growing bacteria were counted with counter coloni. Requirements for bacteria can be calculated that is 30-300 range. Then do the calculation of the number of colonies using the local standard method that is following SNI 01-2332.3-2006 about testing the total plate counter. The calculations are as follows:

$$
\mathrm{N}=\frac{\Sigma \mathrm{C}}{\left[\left(1 \mathrm{Xn}_{1}\right)+\left(0.1 \mathrm{Xn}_{2}\right)\right] \mathrm{Xd}}
$$

Note:

$\mathrm{N}$ : The number of product colonies is expressed in colonies per $\mathrm{mL}$

$\Sigma \mathrm{C}$ : Number of colonies in all plates counted $\mathrm{n}_{1}$ : The number of plates in the first dilution calculated

$\mathrm{n}_{2}$ : the number of plates in the second dilution calculated

d: first calculated dilution

\section{Survival Rate}

Fish survival rate was used to determine the survival rate of test fish by comparing the number of fish at the beginning of the study and fish that were still alive at the end of the research. According to Maftuch et al., (2014), survival rates can be calculated using the following formula:

$$
\mathrm{SR}=\frac{N t}{N o} \times 100
$$

Information :

$\mathrm{SR}=$ Survival $(\%)$

$\mathrm{N}_{\mathrm{t}}=$ number of live fish at the end of the study (tail)

$\mathrm{N}_{0}=$ Number of live fish at the beginning of the study (tail)

\section{Water quality}

Water quality parameters measured in this study were the level of dissolved oxygen (DO) using DO meter, water temperature using thermometer and $\mathrm{pH}$ using $\mathrm{pHmeter.}$

\section{Data analysis}

\section{Data analysis}

Data obtained at the time of the study were analyzed statistically accordance to the experimental design used i.e. Complete Randomized Design (CRD). Then analyzed statistically using ANOVA.

\section{Result}

\section{Antibody titer}

The results of antibody titer agglutination test that occurred in the sample after squid ink powder was given up to the 7 th day can be seen in Table 1 and Figure 1..Anti body titer was 0 for all treatment at the beginning of treatment.

Table 1 . Antibody titer at day 4 and 7

\begin{tabular}{llll}
\hline No & Treatment & Day 4 & Day 7 \\
\hline 1 & A $(52.5 \mathrm{ppm})$ & $06.67 \pm 02.31$ & $06.00 \pm 03.46^{\mathrm{a}}$ \\
2 & B $(62.5 \mathrm{ppm})$ & $26.67 \pm 09.24$ & $13.00 \pm 04.62^{\mathrm{b}}$ \\
3 & C $(72.5 \mathrm{ppm})$ & $16.00 \pm 00.00$ & $08.00 \pm 00.00^{\mathrm{ab}}$ \\
4 & Positive control $(\mathrm{K}+)$ & $42.67 \pm 18.48$ & $26.67 \pm 09.24^{\mathrm{bc}}$ \\
5 & Negative control $(\mathrm{K}-)$ & $05.33 \pm 02.31$ & $02.67 \pm 01.15^{\mathrm{a}}$ \\
\hline
\end{tabular}




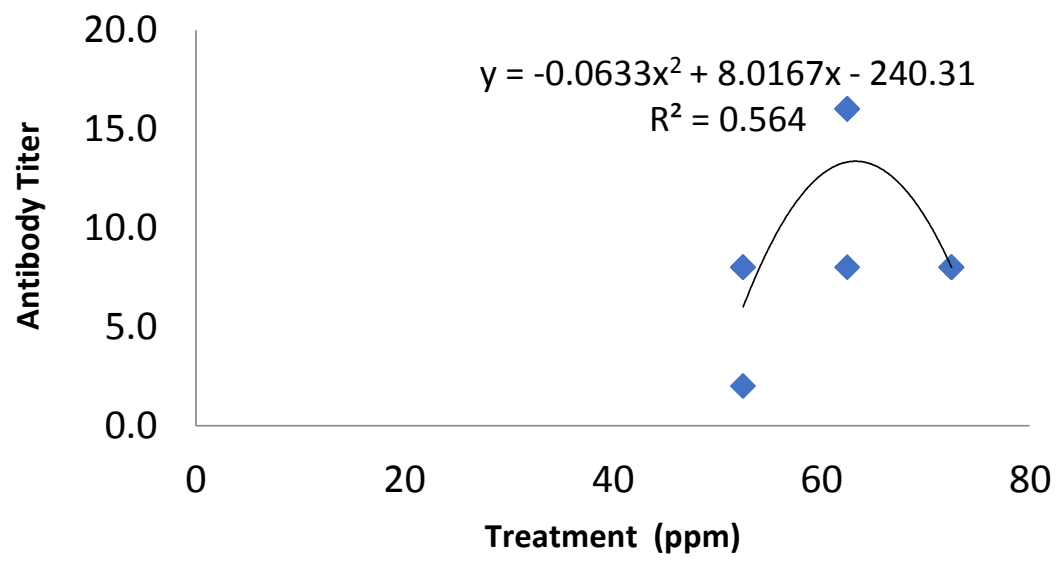

Figure 1. Relationship between squid ink powder treatment and Antibody titer

\section{Bacteria in fish blood}

Bacterial density in tilapia blood was one of the main parameters in this study. The results of the calculation of the density of bacteria in the blood each treatment before administering squid ink powder can be seen in Table 2.

Table 2. Bacteria density $\left(10^{3} \mathrm{cfu} / \mathrm{mL}\right)$

\begin{tabular}{llccc}
\hline No & \multicolumn{1}{c}{ Treatment } & Day 1 & Day 4 & Day 7 \\
\hline 1 & A (52.5 ppm) & $258.47 \pm 05.50$ & $256.33 \pm 16.17$ & $286.33 \pm 07.24^{\mathrm{b}}$ \\
2 & B (62.5 ppm) & $247.00 \pm 17.50$ & $210.33 \pm 59.52$ & $166.33 \pm 50.17^{\mathrm{a}}$ \\
3 & C (72.5 ppm) & $246.00 \pm 19.69$ & $279.00 \pm 45.74$ & $284.33 \pm 58.61^{\mathrm{b}}$ \\
4 & Positive control (K+) & $267.00 \pm 56.86$ & $272.00 \pm 48.39$ & $284.00 \pm 36.76^{\mathrm{ab}}$ \\
5 & Negative control (K-) & $268.00 \pm 41.03$ & $294.33 \pm 34.53$ & $328.33 \pm 56.09^{\mathrm{b}}$ \\
\hline
\end{tabular}

\section{Survival rate}

Observation of tilapia (O. niloticus) survival rate was carried out at the first crossing after being infected until the end of the $7^{\text {th }}$ day of research. During the infection, there was no death in fish so the survival value was $100 \%$ in all treatments. Table 3 shows that the relative survival values varied with each treatment.

Table 3. Survival rate

\begin{tabular}{llc}
\hline No. & \multicolumn{1}{c}{ Treatment } & Average Survival Rate (\%) \\
\hline 1 & A $(52.5 \mathrm{ppm})$ & $85.71 \pm 10.41^{\mathrm{b}}$ \\
2 & $\mathrm{~B}(62.5 \mathrm{ppm})$ & $90.47 \pm 05.15^{\mathrm{c}}$ \\
3 & C (72.5 ppm) & $88.00 \pm 07.64^{\mathrm{b}}$ \\
4 & Positive control (K+) & $52.38 \pm 07.90^{\mathrm{c}}$ \\
5 & Negative control (K-) & $40.48 \pm 10.91^{\mathrm{a}}$ \\
\hline
\end{tabular}




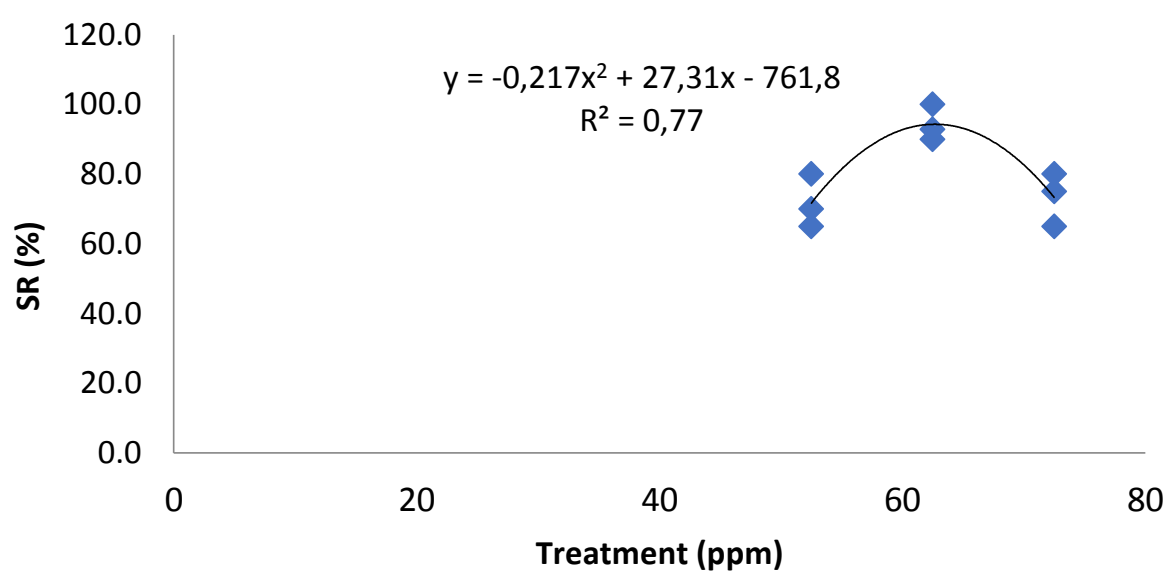

Figure 3. Relationships between treatment and survival rate (SR).

\section{Water Quality}

Water quality measurement during the research can be seen in Table 3. Table 3. Water quality parameter

\begin{tabular}{lll}
\hline Parameter & Measurement & Reference \\
\hline Temperature & $26-28.3^{\circ} \mathrm{C}$ & $24-32^{\circ} \mathrm{C}($ Amri, 2011) \\
$\mathrm{pH}$ & $6.36-7.31$ & $6.5-9.0$ (Arie, 1998) \\
$\mathrm{DO}(\mathrm{mg} / \mathrm{L})$ & $4.52-6.1$ & $>5 \mathrm{mg} / \mathrm{L}$ (Sucipto and \\
& & Prihartomo, 2007) \\
\hline
\end{tabular}

\section{Discussions}

\section{Antibody titer}

Interactions between antigens and antibodies can cause various effects. One of them is agglutination. The results of the agglutination test are used to determine the ability of squid ink powder the feed to increase the tilapia antibody. Agglutination occurs marked by the formation of cloud-shaped clumps on the microplate. Clots are formed because of the bonds between antigens and specific antibodies in blood serum. Antigens and antibodies can bind because there are receptors on antibodies, whereas on antigens there are epitopes. Both can bind because they are influenced by the hydrophobic, ionic and hydrogen forces (Sadikin, 2002).

The agglutination test conducted on tilapia antibodies explained that an increase in antibody titer after squid ink powder was given and a decrease in antibody titer value after the challenge test. Tilapia antibody titre prior to the administration of squid ink powder in the feed could not be calculated because there was no agglutination because no specific antibodies were performed in blood serum samples of Tilapia. Agglutination was not formed in all treatments so the antibody titer value was 0 . Antibody titers reflected the body's defense capability against bacterial infections through specific immune responses. The higher the titer value, it is expected that the ability to protect against infection is also higher. Antibodies circulating in the blood will neutralize the toxic molecules produced by bacteria (Taukhid and Purwaningsih, 2013).

The antibody titer in the negative control did not increase because the antigen could not bind to the control fish serum. Fish serum was suspected to have no specific antibodies because there was no stimulation by similar antigens, so the antigens that were dripped into serum were not able to bind the molecules contained in the serum. Based on observations of agglutination wells, clumping did not occur in the treatment, but the antigen precipitated at the bottom of the microplate well and formed a point.

Based on Table 1, the value of tilapia $(O$. niloticus) antibody titer after administration of squid ink powder has increased from before of squid ink powder was administered. Antibody titer was the opposite of the value of dilution in the last well that agglutination occurred. 
The relationship between different dosages of squid ink powder (Loligo sp.) to tilapia antibody titers produces a quadratic graph showing that at certain doses of squid ink powder can work as antibacterial as indicated by an increase in tilapia antibody titer value in treatment B $(62.5 \mathrm{ppm})$ as the best result, but if the dose is increased the tilapia antibody titer value will decrease again caused by the use of alkaloids for the process of bacterial growth. While treatment B was lower than control positive $(\mathrm{K}+)$ which using $20 \mathrm{ppm}$ oxytetracycline. The resulting relationship or graph is quadratic as evidenced by the equation $\mathrm{y}=0.063 \mathrm{x}^{2}+8.016 \mathrm{x}-240.3$ with a coefficient of determination $\mathrm{R}^{2}$ of 0.56 . According to Fitrial and Khotimah (2017), melanin from squid ink has anti-tumor activity by inhibiting plasmin activity to increase thromboxane and enhance the immune system to kill cancer cells. In addition, melanin also acts as an antioxidant, anti-radiation, and antirotavirus. Cuttlefish ink and or squid have antibacterial activity.

\section{Bacterial density}

The treatment by giving squid ink powder which has the highest bacterial density is in the K-treatment with an average bacterial density of $294 \times 10^{3} \mathrm{cfu} / \mathrm{mL}$ and the lowest bacterial density is in treatment B $(62.5 \mathrm{ppm})$ with an average bacterial density of $211 \times 10^{3}$ $\mathrm{cfu} / \mathrm{mL}$.

Based on Table 2 can be seen the average results of the calculation of bacterial density at the end of the maintenance period after treatment. Treatment with squid ink (Loligo sp.) which had the highest bacterial density was in the K- with a mean bacterial density of $329 \times 10^{3} \mathrm{cfu} / \mathrm{mL}$ and the lowest bacterial was in treatment $\mathrm{B}(62.5 \mathrm{ppm})$ with the average bacterial density $167 \times 10^{3} \mathrm{cfu} / \mathrm{mL}$.

Relationship between differences in squid ink powder to the density of $A$. hydrophila produces a quadratic relationship or graph with the equation of $\mathrm{y}=1.19 \mathrm{x}^{2}-148.85 \mathrm{x}+$ 4821 which means that at certain doses of squid ink powder can work as an antibacterial which is characterized by a decrease in bacterial density but if the dose is increased the bacterial density will return rose caused by the use of alkaloids for the process of bacterial growth.
From the three treatments, the best and most efficient results were treatment $B$ with a dose of $62.5 \mathrm{ppm}$ squid ink powder because it had an average lower bacterial density when compared to other treatments, which was $167 \times 10^{3} \mathrm{cfu} / \mathrm{mL}$. According to Sahu et al. (2011), the pathogenicity of Aeromonas can be caused by many factors. Extracellular products from both bacteria are suspected as one of the virulence factors that contain several enzymes and hemosillin which cause cytotoxic, cytolytic, hemolytic and enterotoxic in infected fish.

Squid ink powder contents alkaloid (Affandi et al., 2019), the largest group of secondary metabolites which are nitrogenbased and alkaline, some alkaloids have benefits in the treatment process. In addition, squid ink also contains fat and glycosaminoglycan. Melanin from squid ink has anti-tumor activity and antibacterial activity (Fitrial and Khotimah, 2017). Fadjar et al. (2016) said from the GC-MS test results it was known that squid ink extract contained oleic acid compounds. The content of oleic acid in squid ink extract can kill bacteria directly. Oleic acid in squid inks can stick to bacterial membranes (for example, ceragenin and lipopeptides), which then damage the structure of bacterial cell walls.

\section{Survival Rate}

The best treatment was B (62.5 ppm) because it gave the highest survival rate i.e. $90.47 \%$,bigger than other treatments but same as positive control which using antibiotics.

Pelczar and Chan (1986) argue that the higher the concentration of antimicrobials used, the faster in killing bacteria, but the use of too high concentrations is less effective in treatment because it can kill fish and also less economical in its use.

Squid ink is an alkaloid. Alkaloids are the largest group of secondary metabolites which are nitrogen-based and alkaline, some alkaloids have benefits in the treatment process. In addition, squid ink also contains fat and glycosaminoglycan. Melanin from squid ink has anti-tumor activity and antibacterial activity (Fitrial and Khotimah, 2017). Fadjar et al. (2016) also added that from the GC-MS test results it was known that squid ink extract contained oleic acid compounds. The content 
of oleic acid in squid ink extract can kill bacteria directly. Oleic acid in squid inks can stick to bacterial membranes (for example, ceragenin and lipopeptides), which then damage the structure of bacterial cell walls. Inhibition can occur after 24 hours of incubation. Based on this it can be concluded that the ink in squid can act as an antibacterial if the concentration is high.

Water quality measurement during conducted research was in good condition for tilapia culture.

\section{Conclusion}

Giving squid (Loligo sp.) ink powder at a dose of $62.5 \mathrm{ppm}$ (treatment B) in tilapia against A.hydrophilla gives the best results with antibody titer $13.00 \pm 04.62 \%$ and decreases the density of bacteria in the blood of tilapia $167 \times 10^{3} \mathrm{cfu} / \mathrm{mL}$, and increase survival rate up to $90.47 \%$.

\section{Acknowledgement}

We would like to thanks the $7^{\text {th }}$ squid ink team for their contribution and hardworking for finishing this research.

\section{References}

Affandi, R. I., M. Fadjar and A. W. Ekawati. 2019. Active Compounds on Squid (Loligo sp.) Ink Extract Powder as Immunostimulant Candidate to Against Shrimp Disease. Research Journal of Life Science. 6 (3) : 150-161.

Arie, U. 1998. Pembenihan dan Pembesaran Nila Gift. Penebar Swadaya. Jakarta. 128 hlm

Fadjar, M., S. Andajani and K. Zaelani. 2016. Squid (Loligo edulis) ink raw extract as an anti-vibriosis substance in grouper (Epinephelus fuscoguttatus) juvenile culture infected by Vibrio alginolyticus. AACL Bioflux. 9(2) : 422- 428.

Fitrial, Y. dan Khotimah, I. K. 2017. Aktivitas antibakteri dari melanin tinta sotong dan cumi-cumi. Jurnal Pengolahan Hasil Perikanan Indonesia. 20 (2) : 266-274

Hartika, R., Mustahal dan A. N. Putra. 2014. Gambaran Darah Ikan Nila (Oreochromis niloticus) dengan Penambahan Dosis Prebiotik Yang Berbeda Dalam Pakan. Jurnal Perikanan dan Kelautan. 4(4) : 259-267.
Khairuman dan K. Amri. 2011. 2,5 Bulan Panen Ikan Nila. Agromedia Pustaka. Jakarta. 202 p..

KKP. 2014. Ministry of Marine Affairs and Fisheries of the Republic of Indonesia. $214 \mathrm{hlm}$

Liu, L., Gong, Y.-X., Zhu, B., Liu, G.-L., Wang, G.-X., \& Ling, F. (2015). Effect of a new recombinant Aeromonas hydrophila vaccine on the grass carp intestinal microbiota and correlations with immunological responses. Fish Shellfish Immunology, 45, 175-183.

Miranti, S. 2016. Pengendalian infeksi Vibrio harveyi pada udang vaname dengan ekstrak kunyit sambiloto dalam pakan di karamba jaring apung Kepulauan Seribu. Tesis. Institut Pertanian Bogor. 52 hlm.

Mubarak, Z., S. Chismirna dan H. H. Daulay. 2016. Aktivitas antibakteri ekstrak Propolis Alami dari Sarang Lebah TErhadap Pertumbuhan Enterococcus faecalis. $J$ Syiah Kuala Dent Soc. 1(2): 175-186.

Mulia, D. S. 2012. Vaksinasi Lele Dumbo. Pustaka pelajar, Yogyakarta. $92 \mathrm{p}$.

Nazir, M. 2005. Metode Penelitian. Bogor: Ghalia Indonesia Cetakan 6.88 p

Pelczar, M. J. dan E.C.S. Chan. 2005. Dasardasar Mikrobiologi. UI Press, Jakarta. 89 p.

Royan, F., S. Rejeki dan A. H. C. Haditomo. 2014. Pengaruh Salinitas yang Berbeda terhadap Profil Darah Ikan Nila (Oreochromis niloticus). Journal of Aquaculture Management and Technology. 3(2): 109-117

Sadikin, M. 2002, Biokimia Darah.. Widya Medika: Jakarta.p:53.

Sahu, I., B. K. Das, N. Marhual, M. Samanta, B.K. Mishra, and A. E. Eknath. 2011. Toxicity of crude extracellular product of Aeromonas hydrophila on Rohu, Labeo Rohita (Ham.). Indian J. Microbiol. 51 (4): 515-520.

Sari, N. W., I. Lukistyowati dan N. Aryani. 2012. Pengaruh pemberian temulawak (Curcuma xanthorriza Roxb) terhadap kelulushidupan ikan mas (Cyprinus carpio L) setelah di infeksi Aeromonas hydrophila. Jurnal perikanan dan kelautan. 17 (2): 12-19.

Salah, M.A, Aqel, S.A., Arshad, H.R., \& Nashwa, M.A.A. (2015). The response of new-season nile tilapia to Aeromonas hydrophila vaccine. 
International Journal of clinical, 8(3), 4508-4514.

Sucipto, A dan R. E. Prihartono. 2007. Pembesaran Nila Merah Bangkok. Penebar Swadaya. Jakarta. 156 p.

Sugiani, D., Taukhid, U. Purwaningsih, dan A. M. Lusiastuti. 2018. Vaksin Kering Beku Sel Utuh Bakteri Aeromonas hydrophila Untuk Pencegahan Penyakit Motile Aeromonads septicemia pada Ikan Lele, Nila dan Gurami. Jurnal Riset Akuakultur. 13 (2): 59-167.

Taukhid dan U. Purwaningsih. 2011. Penapisan isolat bakteri Streptococcus spp. sebagai sebagai kandidat antigen dalam pembuatan vaksin, serta efikasinya untuk pencegahan penyakit streptococcosis pada ikan nila, Oreochromis niloticus. Jurnal Riset Akuakultur. 6: 103-118.

Wahjuningrum, D., Astrini, R., \& Setiawati, M. 2013. Pencegahan Aeromonas hydrophila pada benih ikan lele menggunakan bawang putih dan meniran Prevention of Aeromonas hydrophila on catfish juvenile using garlic and shatterstone herb. Jurnal Akuakultur Indonesia. 12(1): 86-94. 